\title{
The impact of macroeconomic and financial factors on shadow banking in the new EU member states*
}

\author{
Jordan Kjosevski ${ }^{1}$, Mihail Petkovski ${ }^{2}$, Aleksandar Stojkov ${ }^{3}$
}

\begin{abstract}
The goal of this paper is to examine the impact of macroeconomic and financial determinants of the shadow banking dynamics in the selected 11 new EU member states using yearly data from 1999-2018. We apply three methods: fixed effects model, the difference-GMM and the system-GMM (Generalized Method of Moments). Empirical results provide evidence that the most important factors are the developments in the financial sectors (insurance and pension sectors), banking sector, money market rate, as well as the general economic growth. We also found that global financial crisis has a negative impact on the shadow banking growth. From the results we may conclude that traditional banks, insurance sector and pension funds are complementary with shadow banking. This results was opening new issues for macroprudential policy, bearing in mind the Basel III norms. Namely, one of the main goals of Basel 3 is to reduce procyclicality of bank lending, and the rise of shadow banking may have an impact on both capital-based regulation and income-based limits.
\end{abstract}

Key words: shadow banking, EU new member states, panel data analysis

JEL classification: E44, E52, G21, G23

\footnotetext{
* Received: 30-06-2020; accepted: 20-11-2020

${ }^{1}$ PhD in economics, Independent researcher Pitu Guli 5, Ohrid, The Republic of Macedonia. Scientific affiliation: macroeconomics, financial management. Phone: +389078 247717. E-mail: jordan_kos@yahoo.com.

2 Full Professor, Faculty of Economics, University Ss. Cyril and Methodius in Skopje, Blvd. Goce Delchev 9V, 1000 Skopje, The Republic of Macedonia. Scientific affiliation: financial markets and institutions, international finance and macroeconomics.E-mail: mihail.petkovski@eccf. ukim.edu.mk.

${ }^{3}$ Full Professor, Iustinianus Primus Law Faculty, University Ss. Cyril and Methodius in Skopje, Blvd. Goce Delchev 9b, 1000 Skopje, The Republic of Macedonia. Scientific affiliation: economics, management.E-mail: a.stojkov@pf.ukim.edu.mk.
} 


\section{Introduction}

Shadow bank financing is a valuable alternative to bank financing for many firms and households, fostering competition in the supply of financing and supporting economic activity. Hence, it can constitute a useful part of the financial system (Pozsar, 2010; FSB, 2011; EC, 2012). However, shadow bank financing may also become a source of systemic risk, both directly and through its interconnectedness with the conventional banking system, if it involves activities that are typically performed by banks, such as maturity/liquidity transformation and creation of leverage (FSB, 2019).

While this is a remarkably interesting topic, there have not been many studies that provide empirical evidence on the determinants of shadow banking. The explanations vary from lack of statistical data on shadow banking to the ambiguity of its definition (IMF, 2014). Namely, the Financial Stability Board (FSB, 2011) offers two definitions of the shadow banking system. The broad definition is that it encompasses "credit intermediation involving entities and activities outside the regular banking system", whereas the narrow definition refers to "a system of credit intermediation that involves entities and activities outside the regular banking system, and raises (1) systemic risk concerns, in particular by maturity/ liquidity transformation, leverage and flawed credit risk transfer, and/or (2) regulatory arbitrage concern." Wesley (2014: 317) defines the shadow banks as "private financial entities that create ex-nihilo credit-money without deposits". More specifically, Guttmann (2016) conceptualizes four pillars of shadow banking: money markets; repurchasing agreements; securitization; and over-the-counter derivatives (e.g., swaps and credit derivatives). Shadow banks are often less regulated than traditional banks, lack a formal safety net and typically receive indirect or implicit enhancements (e.g., Claessens and Ratnovski, 2014).

The shadow banking in European context has unique roots, as it occurs both outside and partially within the banking system. For instance, the European Economic and Social Committee (EESC, 2012) underlined [that] "there are many ways in which shadow banks replicate traditional banks, and some shadow banks are part of traditional banks." Jeffers and Plihon (2014) trace back the blossoming of market-based financing (shadow banking) in Europe to the financialization and the extensive financial deregulation in 1980s. As opposed to the diverse non-bank financial intermediaries in the "old" EU member states, the main entities that form the shadow banking system in Central, Eastern and South-Eastern Europe are simple and easy to identify (Ghosh et al., 2012).

Definitional ambiguities offer only a partial explanation for the scarce empirical literature. Most of the studies are still in an incipient or a working-paper stage, and mainly focus on the United States, the United Kingdom, or the euro area countries, while the new EU member states remain slightly neglected. These countries in the 
past shared a socialist central planning system and to day they still invest significant efforts in order to establish a well-functioning financial system, thus depriving shadow banking of a context that could allow for its institutions and activities to flourish Du Li et al. (2017).

This paper therefore aims to fill an important gap in the literature and to empirically estimate how selected determinants will affect the dynamics of shadow banking sector in selected 11 new EU Member States. We provide a sector decomposition to better understand the underlying trends and tendencies. Furthermore, the panel data estimation techniques involve static and dynamic (General Method of Moments, GMM) models and explore the role of potential drivers of shadow banking, which are frequently discussed in the related literature.

The basic hypothesis of this paper is that selected macroeconomic and financial factors have statistically significant impact on shadow banking growth.

Our article contributes to the advancement of the knowledge on shadow banking, by providing information on development and determinants in the 11 new EU Member States. We believe that a deeper understanding of the shadow banking determinants may help national policy makers to mitigate the related risks, while benefiting from the main advantages.

The remainder of the article is organized as follows: Section 2 overviews some of the main empirical findings on the size, scope and determinants of shadow banking; Section 3 describe the data and methodology; and Section 4 presents the empirical results. Section 5 outlines the conclusions of the research.

\section{Literature review}

As already noted, most of the existing studies on shadow banking focus on the United States and to a lesser extent on Europe (e.g., Girasa, 2016; Nesvetailova, 2018). Even though shadow banking extends well before the Global Financial Crisis (GFC), our focus is on the post-crisis research. The academic literature in European context has progressed along several strands: (1) examinations of the size and evolution of shadow banking (e.g., Maddaloni et al., 2011; Grillet-Aubert et al., 2016; Malatesta et al., 2016); (2) investigations of potential determinants behind the decade-long boom of the shadow banking system (e.g., Barbu et al., 2016; Grillet-Aubert et al., 2016; Hodula, 2018; 2019; Apostoaie and Bilan, 2019); (3) assessments of the implications of shadow banking for systemic risk, financial stability, and growth (e.g., Lysandrou and Nesvetailova, 2015; Dumičić and Ridzak, 2016; Langfield and Pagano, 2016); (4) analyses of jurisdictional competition, regulation and supervision of shadow banking (e.g., O'Sullivan and Kinsella, 2012; 2013; Adrian, 2014). Given the main hypothesis, our literature review is 
limited only to the first two strands of the empirical literature. Surprisingly, little empirical work has been done to analyze the relative importance of specific driving forces for the development of a shadow banking system, suggesting that obstacles or challenges to such research do exist. Another signal of the analytical gap in the literature on shadow banking in Europe is that many studies exist as working papers, rather than as published work in refereed journals.

Academic attempts for measuring shadow banking have encountered problems in defining its scope. Some authors adopted a broad definition, encompassing all non-monetary financial institutions, with exception of pension funds and insurance companies (Bakk and Simon et al., 2012; Apostoaie and Bilan, 2020). Other studies using higher frequency data apply a narrower definition in European context, by also excluding the money market funds, due to a lack of quarterly data (e.g., Apostoaie and Bilan, 2020). The implications can be sizable.

Due to the complexity of the phenomenon and data limitations, authors and institutions have either resorted to entity-based or activity-based measurement approaches. The entity-based approach to measuring shadow banking is based on aggregation of the financial assets of selected non-monetary financial intermediaries (e.g., Pozsar et al., 2013). Some authors use the gross value of financial assets (e.g. Apostoaie and Bilan, 2019), whereas others (e.g., Barbu et al., 2016) use the net value of total assets. The entity- or institution-based approach has drawbacks, as some intermediaries may not (fully) engage in shadow banking activities. For instance, the Financial Stability Board excludes financial activities with no direct relation to credit intermediation (e.g., equity investment funds) or activities that are already consolidated into banking groups (FSB, 2014; 2015; Agresti and Brence, 2017). To remedy this definitional problem, other studies adopted an activity-based approach, focusing on financial instruments or markets (e.g., Gorton and Metrick, 2012; Mehrling et al., 2013; Claessens and Ratnovski, 2014). For example, Botta et al., (2018) explain that shadow banking is based on three main activities (processes) connecting commercial banks and financial firms: (1) securitization of mortgages by commercial banks; (2) production and issuance by financial firms of structured financial products, and (3) provision by commercial banks of credit to financial firms through the repo market. Although methodologically sounder, to our best knowledge, the 'pure' activity-based approach has not been applied in the European case, because of data limitations.

The empirical literature has identified several hypotheses regarding the main driving forces of shadow banking: (1) the procyclicality and high liquidity hypotheses: overall macroeconomic and global liquidity factors; (2) the search for yield hypothesis: financial products offered outside the traditional banking system usually bring a higher yield; (3) the complementarity hypothesis: shadow banking grows together with the conventional banking system, as it can expand access to credit, enhance maturity transformation, and promote risk sharing; (4) 
overcapitalization/substitution hypothesis: the high capital requirements, high funding costs and regulation burden in the traditional banking system contributes to the very phenomenon of shadow banking; (5) the institutional cash pool hypothesis: the demand from institutional investors contributes to the development of shadow banking. Given the limited number of empirical investigations of the determinants of shadow banking in European context, we present the main findings in these studies by associating them with the dominant hypotheses.

IMF (2014) analyzes the determinants of shadow banking in a set of 26 mostly developed economies, covering some European countries over the 19902013 period. The study highlights that tightening bank capital requirements creates incentives for banks to shift their activities to the non-bank sector, hence positively influencing the growth of shadow banking. In addition, the size of the banking sector is positively correlated with the extent of shadow banking, thereby supporting the complementarity hypothesis. Furthermore, the results show that the relationship between institutional investors' growth and shadow banking development is positive. The results of the study indicate a negative relationship between real short-term interest rates and shadow banking growth.

Malatesta et al. (2016) estimated the determinants of shadow banking in the euro area countries over the period 1999Q1-2014Q.The results of their study show that as a main determinants of shadow banks are: the GDP growth, inflation, and the term spread). They also find evidence of a possible crowding-out effect, suggesting that the growth rate of loans from traditional banks is inversely related with the relative role of shadow banks.

The empirical literature does not offer an explicit support for the procyclicality hypothesis. Barbu et al. (2016) estimate the macroeconomic determinants of shadow banking for a panel of $15 \mathrm{EU}$ member states (including four CEE economies) using quarterly data (2008Q1-2015Q3). As a proxy for shadow banking, they use the net value of total assets. On one hand the results of their paper shows that longterm interest rates and stock index have positive impact of shadow banking, while on the other hand the shadow banking is negatively associated with GDP growth, development of investment funds, liquidity and short-term interest rates.

Furthermore, Hodula (2018) analyzed determinants of shadow banking growth using data of $24 \mathrm{EU}$ countries for the period 2004-2017. The results show that the EU shadow banking system is positively correlated to more stringent capital regulation, increasing demand of long-term institutional investors, financial development and interest rates in the economy. Based on the results of the empirical model, the author concludes that the main determinants of shadow banking were different in the old and new EU member states, mainly due to the missing legal framework for securitization in the new members. Hodula (2019) provides empirical evidence that the tightening of monetary conditions negatively affected 
the growth of traditional banking but strengthened the growth of shadow banking. This lends some support to the validity of the substitution hypothesis during monetary tightening.

Apostoaie and Bilan (2019) estimated the determinants of shadow banking dynamics in $11 \mathrm{EU}$ member states from Central and Eastern Europe (CEE) over the period 2004-2017, using fixed-effects estimation and a quarterly data. They applied two dependent variables that correspond to two different measures of the shadow banking sector - the broad one (including all non-monetary financial institutions, except insurance corporations and pension funds) and the narrow one (excluding from the above one the investment funds other than money market funds). They used six macroeconomic and financial variables as independent determinants.

Country-specific empirical investigations of shadow banking also shed light on the driving forces, but these studies are even more scarce. Hodula et al. (2020) investigate the Czech shadow banking sector over the last decade and find evidence in favor of the procyclicality and complementarity hypotheses.

Despite the great interest in the topic, most studies refer to the developed countries, whereas emerging markets and developing economies are deprived of a more indepth investigation of this phenomenon.

\section{Methodology}

In order to analyse the determinants that affected the shadow banking in the new EU Member States, we conducted a panel data analysis. We opted for this type of analysis as it provides several benefits (Hsiao, 2003): (1) the use of panel data enables us to control for individual heterogeneity; (2) panels provide more informative data, more variability, less collinearity among the variables, greater degree of freedom, and higher efficiency; (3) with panel data, one is better equipped to study the dynamics of adjustment; (4) panel data are more suitable for identifying and measuring effects that are simply not detectable in pure cross-sections or pure time-series data, and (5) panel data models allow for the construction of and testing more complicated behavioural models than pure cross-section or time data models.

In order to provide consistent and unbiased results, we implemented three alternative estimation techniques. Our analysis we start with the assessment of fixed and random effects With the fixed- effects model, we assume that the units of interest (in our case, countries) are fixed, and that the differences between them are not of interest. On the other hand, with the random model, we assume that the units are a random sample extracted from a larger population. Accordingly, for our analysis of the 11 new EU Member States from Central, Eastern and South-Eastern Europe, the model of fixed effects will be adequate, since the data set covers all 
11 new EU member states and the conclusions drawn from this analysis will only apply to them. In addition, we will also conduct the statistical test of Hausman (1978) for distinguishing between the models of fixed and random effects.

The specification (2) of the empirical model with fixed effect is as follows:

$$
y_{i t}=x_{i t} \beta+\tau_{t}+\delta_{i}+\varepsilon_{i t}
$$

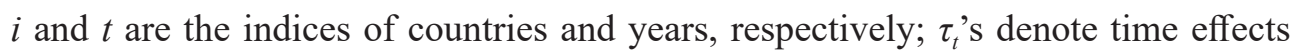
to capture macroeconomic circumstances; $\delta_{i}$ 's are called unobserved country fixed effects; $\varepsilon_{i t}$ 's are all unobserved idiosyncratic errors (i.i.d); $y_{i t}$ 's are the broad measure of shadow banking as a percent of GDP of country $i$ in period $t, x_{i t}$ 's contain control variables, and $\beta$ is the coefficient vector that we are interested in. Thus, we estimate models with fixed effects estimator, allowing for the correlation between $\delta_{i}$ and $x_{i t}$.

While the approach is rather simple and intuitive, this model is not suitable forour paper due to potential inertia of the dependent variable. Namely, the assets of OFI in our model can involve persistence in their movement, that is, its present value to a certain extent depends on its past value. Bearing this in mind, we are more inclined to employ a dynamic panel estimation (3) as follows:

$$
y_{i t}=\sum_{j=1}^{p} \alpha_{j} y_{i, t-j}+x_{i t} \beta+\tau_{t}+\delta_{i}+\varepsilon_{i t}
$$

The dynamic model includes lagged dependent variables, $y_{i, t-j}$. It also allows for the correlation between $\delta_{i}$ and $x_{i t}\left(\operatorname{cov}\left(\delta_{i}, x_{i t}\right) \neq 0\right)$. In order to capture the persistence of the assets of OFI and to eliminate the fixed effects (and their correlations), we difference the model and adopt the difference Generalized Method of Moments including the lagged difference of the dependent variable was introduced by Arellano and Bond (1991). We use the one-step generalized method of moments estimator (GMM) developed by Arellano-Bond (1991), because according to Judson and Owen (1999), his estimator outperforms the two-step estimator both in terms of producing a smaller bias and a smaller standard deviation Then, we obtain

$$
\Delta y_{i t}=\sum_{j=1}^{p} \alpha_{j} \Delta y_{i, t-j}+\Delta x_{i t} \beta+\Delta \tau_{t}+\Delta \delta_{i}+\Delta \varepsilon_{i t}
$$

In the differenced model (4), there still exists a correlation between lagged values of dependent variable $\Delta y_{i, t-j}$ and the differenced errors, $\Delta \varepsilon_{i t}$. According to Nickell (1981), the standard fixed effects estimator is not consistent, because this correlation produces biased estimates. Bearing this in mind, we employ the system-GMM estimator based on Arellano and Bover (1995) and Blundell and Bond (1998), which addresses the endogeneity problem caused by the correlation. 
In order to avoid the problem of too many instruments in comparison to the number of groups (Roodman, 2009), the number of instruments are kept lower than the number of countries. In the standard (unconstrained) form, each instrumenting variable creates one instrument for each time period and the lag available to that period, whereas - in the collapsed form - a single column vector of instruments is created instead of a whole matrix of instruments. Although collapsing can reduce statistical efficiency in large samples, it can be very helpful as a tool in avoiding the bias in finite samples, which are usually characterized by instrument proliferation. In other words, we control the number of instruments by limiting our analysis to the second lag. This helps avoid any bias due to too many instruments in a relatively small sample. The validity of the parameter estimation instruments selected can be tested using the Hansen test. Furthermore, we will test serial correlations in the differenced residuals (first-order [AR1]) and second-order [AR2] serial correlations). According to Arellano and Bond (1991), the first-order autocorrelation in the differenced residuals does not imply that the estimates are inconsistent. However, the second-order autocorrelation would imply that this is the case.

According to all the above, the analysis in the next section will evaluate the economic model (1) through 3 panel methods: the method of fixed effects, the difference - GMM and the system-GMM methods.

\section{Empirical data and analysis}

For the purposes of this research, we use an unbalanced panel of annual data for 11 NMS from Central, Eastern and South-Eastern Europe (Bulgaria, Croatia, Czech Republic, Estonia, Hungary, Latvia, Lithuania, Poland, Romania, Slovak Republic and Slovenia) for the period 1999-2018. The sample selection is based on similarities in the level of economic and institutional development, historical legacies, geographical and cultural proximity, which greatly influences the creation of economic relations between these countries. The choice of time period in this paper was contingent upon the availability of time series data of all determinants included in the model, particularly of our dependent variable. According to Rinaldi and Sanchis-Arellano (2006), unbalanced panel data allow for more observations and their results are less dependent on a particular period.

The determinants selected in our model are mostly used in the academic literature (Kim, 2016; Barbu et al., 2019; Apostoaie and Bilan, 2019). The data sources used for our model include Eurostat, other databases from credible international and European sources, IMF's International Financial Statistics and Monetary and Financial Statistics database, ECB's Statistical Data Warehouse database and World Bank data. 
The econometric model is depicted by equation (1):

$$
S B_{i t}=\beta_{j} D E T_{j, i, t}+u_{i, t}
$$

where $i$ refers to the country $(i=1-11) ; t$ refers to time periods (years) $(t=1-19)$; $S B$ is the dependent variable; $D E T_{j}$ is a vector of independent variables; $\beta_{j}$ are the coefficients of the explanatory variables, and $u_{i, t}$ are the idiosyncratic (observationspecific) errors.

Before presenting the potential determinants of SB, it is necessary to identify the dependent variable. As mentioned in the literature review, there is no internationally harmonised definition that has been applied in all or most of the countries in the world for a considerable period of time. Bearing this in mind, we follow (Kim, 2016) and Apostoaie and Bilan (2019) and as a measure of shadow banking, we use OFI (total assets of Other Financial Intermediaries, expressed in percent of GDP), as defined by the European Commission and Eurostat. This broad measure of shadow banking encompasses the asset size of OFI, which consists of the financial sector other than banks, pension funds and insurance companies, public financial institutions, and financial auxiliaries. One advantage of the OFI statistics is the high degree of international consistency, thus allowing for comparisons and aggregations across countries (e.g. Broos et al., 2012).

We employ the following explanatory variables:

- macroeconomic determinants: real GDP growth $(g d p g)$; the three-month interbank rate $($ short $)$, and $\mathrm{M} 2 / \mathrm{GDP}$ ratio $(m 2 g d p)$;

- financial determinants: size of banks as a percent of GDP (bank); insurance as a percent of GDP (penetra); and pension funds as a percent of GDP (pens);

- a dummy variable for the occurrence of the Global Financial Crisis 2007-08 (crisis).

Within the core determinants of all previously mentioned studies, the variables related to Gross Domestic Product (GDP) are among the main macroeconomic determinants of shadow banking growth. In this context, several variations of this determinant, such as the annual growth rate of real GDP, the growth rate of income per capita, etc., are well known in the literature. However, the real GDP growth rate is by far the most common macroeconomic determinant, used for example in Duca (2016), Malatesta et al. (2016) and Hodula et al. (2017). For this determinant we expect a positive and significant impact of real GDP growth that is consistent with the shadow banking procyclicality hypothesis mentioned by Adrian and Shin (2009) and empirically evidenced by (Duca 2016; Malatesta et al., 2016; Hodula et al., 2017).

Furthermore, we will follow the approach by Barbu et al. (2016) and include the monetary aggregate M2 in GDP, expecting a negative relationship. This expectation 
comes from the mere composition of M2, which includes the currency in circulation and deposits of all maturities. Namely, if we have a decreasing trend of deposit interest rates, economic agents will be looking to save or invest at higher yields and will tend to shift to other types of financial investments. Furthermore, if bank deposits decrease, this will impact their ability to offer loans. This will lead to a decrease in the money supply through the traditional banking channel, which will be supplemented (substituted) by an increase in the volume of activity of shadow banking.

We include the three-month inter-bank rate in the model in order to capture changes in the monetary policy settings. Regarding this determinant, we may generally assume that it has a negative impact on shadow banking growth, since the lower yields associated with lower market interest rates motivate investors to search for attractive returns in riskier places (the search for yield hypothesis). Yet, there are also studies that document a positive relationship (Den Haan and Sterk, 2011; Loutskina, 2011; Nelson et al., 2017). More specifically, Nelson et al. (2017) elaborate a "waterbed effect" of the monetary policy, i.e. the view that credit extension by banks and non-banks tends to respond in the opposite direction to monetary shocks. Banks can circumvent the increased funding costs by increasing their securitization activity, which leads to a migration of lending beyond the traditional banking system. Bearing this in mind, we expected the impact of this determinant to be ambiguous.

In order to capture any potentially complementary properties of shadow banking vis-à-vis traditional banking, we follow Kim (2016) and include growth of banking sector assets as a percent of GDP. According to Hodula (2018), there is some evidence that not only banks frequently sponsor shadow banking activities, often through financial vehicle corporations, but also traditional banks might be involved in investment funds. In other words, banks originate loans and sell them to brokers and dealers, and hedge funds. The buyers pool and securitize them and then distribute them to investors with different risk appetites, including hedge funds, asset managers, and insurance companies. Pozsar (2008) and Pozsar et al. (2010) illustrate this Originate-to-Distribute model in more detail. Subsequently, we expect a positive association between this determinant and shadow banking.

In our model, we also include variables representing other segments of the financial systems in the countries under investigation: the data on asset size of banks calculated as a percent of GDP; insurance penetration levels; and pension funds as a percent of GDP. We include these determinant, in order to capture complementarities with SBS and demand-side effects. Given the empirical findings by IMF (2014), Malatesta et al. (2016), we expect these variables to be positively associated with the growth of the shadow banking sector.

In addition to these determinants, we will include one dummy variable in the empirical model. We will use a binary dummy for the occurrence of a financial 
crisis to mark the Global Financial Crisis as taking the value of one for the period from 2007 to 2008 and zero for all other periods. The periods of financial crises were selected based on the new European financial crises database (ESRB, 2017).

Table 1 presents the descriptive statistics for the determinants involved in the regression model. According to Table 1, there were missing data observations for nearly all determinants. Moreover, there are significant differences among the countries in all selected variables. An example of this heterogeneity is OFI (Other Financial Intermediaries, expressed in percent of GDP) with a minimum of $-39.1 \%$ and a maximum of $445.6 \%$. This is also valid for other variables, such as the GDP growth and the short-term interest rate.

Table 1: Descriptive statistics

\begin{tabular}{|l|r|r|r|r|r|r|r|}
\hline & \multicolumn{1}{|c|}{ OFI } & \multicolumn{1}{c|}{ GDPG } & MONEY & SHORT & BANKGDP & PENETRA & PENS \\
\hline Mean & 24.72 & 3.25 & 51.20 & 5.02 & 55.96 & 2.81 & 6.06 \\
\hline Median & 11.20 & 3.60 & 51.95 & 3.33 & 56.91 & 2.70 & 4.76 \\
\hline Maximum & 445.60 & 11.89 & 84.84 & 74.21 & 105.1 & 6.00 & 27.40 \\
\hline Minimum & -39.10 & -14.81 & 19.81 & -0.33 & 10.9 & 0.71 & 0.02 \\
\hline Std. Dev. & 55.76 & 3.99 & 15.40 & 7.83 & 20.59 & 1.11 & 5.21 \\
\hline $\begin{array}{l}\text { Number of } \\
\text { observations }\end{array}$ & 215 & 220 & 162 & 196 & 202 & 213 & 185 \\
\hline
\end{tabular}

Source: Authors' calculations

Furthermore, we will analyze multi-collinearity among selected determinants. According to Gujarati and Porter (2009), multi-collinearity is a problem when the correlation is above 0.80 . As we presented in Table 2, all correlation coefficients were found to be below this threshold, suggesting the continuation of use of all the variables included in running the regression model.

Table 2: Correlation matrix

\begin{tabular}{|c|c|c|c|c|c|c|c|}
\hline & OFI & GDPG & MONEY & SHORT & BANKGDP & PENETRA & PENS \\
\hline OFI & 1 & & & & & & \\
\hline GDPG & 0.3627 & 1 & & & & & \\
\hline MONEY & -0.1858 & 0.3691 & 1 & & & & \\
\hline SHORT & 0.1961 & 0.1003 & -0.4904 & 1 & & & \\
\hline BANKGDP & 0.2721 & 0.5112 & 0.6344 & -0.2439 & 1 & & \\
\hline PENETRA & 0.0025 & 0.0584 & 0.3643 & -0.0218 & 0.0888 & 1 & \\
\hline PENS & 0.1934 & 0.3767 & 0.5451 & -0.2240 & 0.6307 & 0.2151 & 1 \\
\hline
\end{tabular}

Source: Authors' calculations 
In the next stage, Table 3 depicts the empirical results of thestatic fixed-effects model, and the difference- and system-GMM models. Despite the methodological differences, all approaches arrive at essentially similar results as to the sign and the statistical significance of most variables in the regression specification.

Table 3: Estimation results

\begin{tabular}{|c|c|c|c|}
\hline $\begin{array}{l}\text { Explanatory } \\
\text { variables }\end{array}$ & $\begin{array}{l}\text { Fixed Effects } \\
\text { (FE) Model [1] }\end{array}$ & $\begin{array}{c}\text { Difference GMM } \\
\text { Model [2] }\end{array}$ & $\begin{array}{l}\text { System GMM } \\
\text { Model [3] }\end{array}$ \\
\hline $\begin{array}{l}\text { Lagged dependent variable } \\
O F I_{t-1}\end{array}$ & 1 & $\begin{array}{r}0.28^{* * * *} \\
(0.21) \\
\end{array}$ & $\begin{array}{r}0.11 * * * \\
(0.10) \\
\end{array}$ \\
\hline Constant & $\begin{array}{r}45.21 \\
(24.86)\end{array}$ & $\begin{array}{r}42.25 \\
(21.34) \\
\end{array}$ & $\begin{array}{r}-51.2 \\
(40.19)\end{array}$ \\
\hline \multicolumn{4}{|l|}{ Macroeconomic determinants } \\
\hline $\begin{array}{l}\text { Real GDP growth } \\
(\text { gdpg) }\end{array}$ & $\begin{array}{r}1.76^{* * *} \\
(0.56) \\
\end{array}$ & $\begin{array}{r}4.02 \\
(1.81) \\
\end{array}$ & $\begin{array}{r}4.93 \\
(1.65) \\
\end{array}$ \\
\hline $\begin{array}{l}\text { M2/GDP ratio } \\
(m 2 g d p)\end{array}$ & $\begin{array}{c}-0.20 * \\
(0.27)\end{array}$ & $\begin{array}{r}-1.14 \\
(1.27)\end{array}$ & $\begin{array}{r}-1.27 \\
(0.62)\end{array}$ \\
\hline $\begin{array}{l}\text { Three-month inter-bank rate } \\
\text { (short) }\end{array}$ & $\begin{array}{r}2.91^{* * *} \\
(1.12)\end{array}$ & $\begin{array}{r}2.36 \\
(2.25) \\
\end{array}$ & $\begin{array}{r}4.43 \\
(2.11) \\
\end{array}$ \\
\hline \multicolumn{4}{|l|}{ Financial determinants } \\
\hline $\begin{array}{l}\text { Size of banks as a percent of } \\
\text { GDP (bank) }\end{array}$ & $\begin{array}{r}0.80^{* * *} \\
(0.35)\end{array}$ & $\begin{array}{r}0.57 * * * \\
(0.68) \\
\end{array}$ & $\begin{array}{r}0.60 * * \\
(0.54) \\
\end{array}$ \\
\hline $\begin{array}{l}\text { Insurance funds as a percent of } \\
\text { GDP (penetra) }\end{array}$ & $\begin{array}{r}4.12 * \\
(6.55) \\
\end{array}$ & $\begin{array}{r}1.61 * * \\
(0.17) \\
\end{array}$ & $\begin{array}{c}0.91^{*} \\
(0.56) \\
\end{array}$ \\
\hline $\begin{array}{l}\text { Pension funds as a percent of } \\
\text { GDP (pens) }\end{array}$ & $\begin{array}{r}0.98 \\
(0.61) \\
\end{array}$ & $\begin{array}{r}0.04 \\
(1.93) \\
\end{array}$ & $\begin{array}{l}0.10^{*} \\
(1.36) \\
\end{array}$ \\
\hline $\begin{array}{l}\text { Global Financial Crisis dummy } \\
\text { variable (crisis) }\end{array}$ & $\begin{array}{r}-6.36^{* *} \\
(6.19) \\
\end{array}$ & $\begin{array}{r}-5.93 \\
(5.74) \\
\end{array}$ & $\begin{array}{l}-5.44 \\
(4.25) \\
\end{array}$ \\
\hline Number of countries & 11 & 11 & 11 \\
\hline Hausman test & 0.367 & & \\
\hline $\begin{array}{l}\text { Sargan test (p-value) } \\
\mathrm{H}_{0}: \text { The instruments are valid }\end{array}$ & & 0.665 & 0.345 \\
\hline Arellano-Bond test [AR (1)] & & 0.007 & 0.004 \\
\hline Arellano-Bond test [AR (2)] & & 0.665 & 0.693 \\
\hline
\end{tabular}

Notes: Standard errors are presented in parentheses.

Source: Authors' calculations 
This confirms that our results are robust to different specifications, although the precision of the coefficients estimated differs across different methods used in our study. From a diagnostics perspective, the Sargan test shows that the instruments selected are valid (with a $p$-value of 0.67 for the difference GMM, and 0.35 for the system GMM model). The estimator ensures efficiency and consistency provided that the residuals do not show serial correlation of second order (even though the equations indicate that negative first order autocorrelation is present, this does not imply that the estimates are inconsistent). Inconsistency would be implied if second-order autocorrelation was present (Arellano and Bond, 1991), but this case was rejected by the test for $A R(2)$ errors. As Roodman (2009: 128) highlights, dynamic panel estimators are more appropriate for "small $T$, large $N$ " panels. Given that the number of countries $(N)$ in our sample is small, the dynamic panel bias becomes insignificant, and a more straightforward fixed-effects estimator could be more appropriate.

The lagged dependent variable is statistically significant and has apositive value in the difference and system GMM models, confirming the dynamic character of the models and the persistence of shadow banking system growth.

Among the macroeconomic determinants, we found evidence that the gross domestic product has a significant and positive impact on shadow banking growth in all three models. This relationship emphasizes that higher GDP might lead to an important rise in OFIs. The positive signs are in line with the literature. Namely, according to Ghosh et al. (2012), shadow banking in the sector in the CEE countries (where our 11 NMS also belong), due to its particular structure (consisting mainly of cooperative banks, credit unions, leasing and factoring companies, microfinance companies), is that of providing alternative funding to the economy.

Furthermore, regarding the influence of monetary policy, we report mixed and mostly statistically insignificant results across different model specifications, ranging from positive to negative. Thus, the M2/GDP ratio results show that this determinant has a significant and negative impact on shadow banking growth, but only in the fixed model. The results indicate that, in times of shadow banking expansion, financing through the traditional banking channel decreases, as banks are restricted to create money. When deposit interest rates follow a decreasing trend, economic agents are looking to save or invest at higher yields and tend to shift to other types of financial investments, which the mainstream banking might not provide. Thus, the financial resources collected by banks by means of deposits record a decrease, which further impacts their ability to grant loans. Consequently, the financing of the real economy through bank loans compresses and the money supply through the traditional banking channel decreases, being supplemented by an increase in shadow banking volume of activity (similar to Barbu et al., 2016).

The positive effect of short-term interest rates emphasized in the literature is confirmed by the results of this study in all three models, also showing support of 
the "waterbed" hypothesis of monetary policy for the NMS. The results suggest that tightening the monetary policy might increase the growth of OFIs, implying that a higher cost of funding increases traditional banks' incentives to engage in securitization, carried out and operationalized by OFIs. Our results are consistent with the findings of Den Haan and Sterk (2011), Loutskina (2011) and Nelson et al. (2017).

The results of the coefficients who associated with the banking sector show that this determinant has strong positive effect on shadow banking supporting the view that shadow banking can progress alongside traditional banking. This results that is accompanied with the growth of the traditional bank as Originate-to-Distribute model implies and the existence of some common roots of both processes (the European integration development of ITC technologies, financial innovation).

The results from the financial sectors (insurance and pension funds) are in line with the literature (Lemma, 2016; Kim, 2016; and Hodula, 2018). The empirical results show that these determinants are statistically significant in almost all models and that shadow banking is complementary not only to the banking sector, but to the rest of the financial system as well. Namely, insurance companies provide protection against financial loss and subscribe collateralized debt obligations to invest their cash. On the other hand, pension funds invest in securities issued in the shadow credit intermediation process, such as asset-backed commercial papers, asset-backed securities, and collateralized debt obligations (Hodula, 2018).

As for the dummy variable, which was introduced to cover the global economic crisis, we found that crisis dummy variable was statistically significant at the $1 \%$ level of significance, in all three models. This is likely because banks reduced their activities (primarily lending) during the crisis, while at the same time this meant expansion of OFI products. The results are in line with those of Hodula (2018), but different from those of Apostoaie and Bilan (2019).

\section{Results and discussions}

The results presented in Table 3 confirm that macroeconomic and financial factors play a role in affecting the shadow banking growth. The impact of financial factors is statistically significant and more consistent across the different empirical specifications. Moreover, these results indicate complementarity between the development of shadow banking and therest of the financial system as well. In these economies, shadowbanks provide alternative funding where traditional banking is not able to do soespecially the complementarity could be viewed in the perspective of mortgage financing. Namely where regulatory constrains do not permit traditional banks to provide mortgage on the full property value, shadow banks might step in to offer a way to finance the rest of the borrower's claims. 
Furthermore, the results indicate that the shadow banking system is highly procyclical, owing to the identified positive relationship with real GDP growth. This finding should be viewed in the light of bank regulation, where especially Basel III norms made an effort to reduce bank lending procyclicality. In some countries, shadow loans may turn out to undermine the effectiveness of capitalbased regulations (such as the counter-cyclical capital buffer) or the introduction of loan-to-value limits.

Such results were opening new issues for macroprudential policy, for the current policy debate and for financial stability. This results pointing the need of consider risk factors in analyzing monetary policy effectiveness. Pass -through strength of monetary policy rates through the non-bank financial sector and the banking sector is affected by the resilience of the financial sector. Also this results may consider bearing in mind the Basel III norms, bearing in mind that one of the main goal of Basel III is to reduce procyclicality of bank lending, and the rise of shadow banking may have impact of both capital-based regulation and income-based limits

\section{Conclusion}

Based on the results presented, the hypothesis that selected macroeconomic and financial variables have statistically significant impact on shadow banking growth could be confirmed. The empirical findings of this study show that the shadow banking sector (in terms of total assets of other financial intermediaries as a percent of GDP) has been positively influenced by, among other things, the developments in the financial insurance and pension sectors, banking sector, money market rates, as well as by the general economic growth. We also found that global financial crisis in 2007-2008 has a negative impact on the shadow banking growth. On the other hand, there is a limited evidence that the impact of money supply (M2/GDP ratio) on shadow banking growth is negative, because that result is relevant only in the fixed model. This study complements the existent economic literature by analyzing the determinants of shadow banking growth in the 11 new EU member states. To the best of the authors' knowledge, this is only the second study analyzing the new EU member states.

This study does not face significant limitations, but their removal will certainly contribute to more robust results. Firstly, there are some missing data observations forthe selected determinants over a longer period. The existence of long time series of data would allow for obtaining more accurate and more reliable results. Secondly, the selected variables fail to catch the effects of regulatory arbitrage opportunities on the development of bank-like activities outside the regulated banking system.

The future avenues of conducting research on the phenomenon of shadow banking should be focused on investigating the impact of other potentially relevant 
determinants, such as the effective reserve requirements ratio, the long-term interest rate, and the inflation rate. Furthermore, if data on narrowly defined shadow banking (in accordance with the Financial Stability Board's methodology) emerge for a longer time span, it is believed that additional analysis on the determinants of shadow banking can be conducted from various perspectives. As data accumulates over time, researchers can also apply the method of two- or three-least squares or panel co-integration models. Additional research is needed to estimate not only the size and determinants of the shadow banking system, but also its complexity, interconnectedness, and risk of contagion of the other segments of the financial system.

\section{References}

Adrian, T. (2014) Financial stability policies for shadow banking, FRBNY Staff Reports, Vol. 66, No. 4, New York: Federal Reserve Bank of New York.

Adrian, T., Shin, H. S. (2009) "The Shadow Banking System: Implications for Financial Regulation Financial Stability Review, issue 13, pp. 1-10, https:// EconPapers.repec.org/RePEc:bfr:fisrev:2009:13:1.

Agresti, A., Brence, R. (2017) "Statistical work on shadow banking: development of new datasets and indicators for shadow banking", Irving Fisher CommittteeNational Bank of Belgium Workshop on Data needs and Statistics compilation for macroprudential analysis, Brussels, Belgium, 18-19 May 2017, https:// www.bis.org/ifc/publ/ifcb46p.pdf.

Arellano, M., Bond, S. (1991) "Some tests of specification for panel data. Monte Carlo evidence and an application to employment equations", The Review of Economic Studies, Vol. 58, Issue 2, pp. 277-297, https://doi.org/10.2307/2297968.

Arellano, M., and Bover, O. (1995) "Another Look at the Instrumental Variables Estimation of Error-Component Models", Journal of Econometrics, No. 68, pp. 29-51,https://www.sciencedirect.com/science/article/abs/pii/030440769401642D.

Bakk-Simon, et al. (2012) "Shadow banking in the euro area: An overview", ECB Occasional Paper Series, No. 133, pp. 1-33, https://www.ecb.europa.eu/pub/ pdf/scpops/ecbocp133.pdf.

Barbu, T. C., Boitan, I. A., Cioaca, S. I. (2016) "Macroeconomic determinants of shadow banking-Evidence from EU countries", Review of Economic and Business Studies, Vol. 9, No. 2, doi: https://doi.org/10.1515/rebs-2016-0037.

Blundell, R., Bond, S. (1998) "Initial Conditions and Moment Restrictions in Dynamic Panel Data Models", Journal of Econometrics, Vol. 87, No. 1, pp. 115-143, https://EconPapers.repec.org/RePEc:eee:econom:v:87:y:1998:i:1.

Beck, G. W., Kotz, H.-H. (2016) "Les activities de shadow banking dans un contexte de bas taux d'interet: une perspective de flux financiers. "Revue d'economie financiere, Vol. 121, No. 1, pp. 235-256. 
Bryan, N., Sengupta, R. (2011)“Is Shadow Banking Really Banking?" The Regional Economist, Federal Reserve Bank of St. Louis, pp. 8-13, https://www. stlouisfed.org/ /media/Files/PDFs/publications/pub_assets/pdf/re/2011/d/ shadow banking.pdf.

Claessens, S., Ratnovski, (2014) “What Is Shadow Banking?”, IMF Working Paper, WP/14/25, https://www.imf.org/external/pubs/ft/wp/2014/wp1425.pdf.

Constantin-Marius, A., Bilan, I. (2019) "Macro determinants of shadow banking in Central and Eastern European countries", Economic Research-Ekonomska Istraživanja, Vol. 32, https://doi.org/10.1080/1331677X.2019.1633943.

Du, J., Li, C., Wang, Y. (2017) "A comparative study of shadow banking activities of nonfinancial firms in transition economies", China Economic Review, Vol. 46, pp. S35-S49, https://doi.org/10.1016/j.chieco.2016.09.001.

Duca, J. V. (2016) "How Capital Regulation and Other Factors Drive the Role of Shadow Banking in Funding Short-Term Business Credit", Journal of Banking \& Finance, Vol. 69, pp. 10-24, doi: 10.1016/j.jbankfin.2015.06.016.

EC. (2012) Green paper on shadow banking, http://ec.europa.eu/internal_market/ bank/docs/shadow/green-paper_en.pdf.

ESRB (2017) "EU Shadow Banking Monitor 2017", European Systemic Risk Board: Frankfurt.

Den Haan, W. J., Sterk, V. (2011) "The Myth of Financial Innovation and the Great Moderation", The Economic Journal, Vol. 121, No. 553, pp. 707-739.

Dumičić, M., and Ridzak. T. (2016) "Are Shadow Banks Hiding in Croatia as Well?", Surveys S-20, Croatian National Bank, Zagreb.

FSB. (2011) "Shadow Banking: Strengthening Oversight and Regulation", Recommendations of the Financial Stability Board.

FSB. (2014) Global Shadow Banking Monitoring Report 2014, Retrieved from http://www.fsb.org/wp-content/uploads/r_141030.pdf.

FSB. (2015) Global Shadow Banking Monitoring Report 2015, www.fsb.org/wpcontent/ uploads/global-shadow-banking-monitoring-report-2015.pdf.

FSB. (2019) Global Monitoring Report on Non-Bank Financial Intermediation 2019, https://www.fsb.org/2020/01/global-monitoring-report-on-non-bankfinancial-intermediation-2019/.

Ghosh, S., Gonzalez del Mazo, I., Otker-Robe, I. (2012) "Chasing the Shadows: How Significant Is Shadow Banking in Emerging Markets?", Economic Premise, No. 88, https://openknowledge.worldbank.org/bitstream/handle/10986 $/ 17088 / 724450$ BRI0EP880OWLEDGE0NOTES0SERIES.pdf?sequence= $1 \&$ isAllowed $=\mathrm{y}$.

Global Monitoring Report on Non-Bank Financial Intermediation 20184 February 2019, https://www.fsb.org/wp-content/uploads/P040219.pdf. 
Giron, C., Matas-Mir, A. (2017) "Interconnectedness of shadow banks in the euro area”, Vol. 46, Bank for International Settlements Basel, Switzerland, https:// www.bis.org/ifc/publ/ifcb46r.pdf.

Girasa, R. (2016) Shadow banking. The rise, risks, and rewards of non-bank financial services, New York: Palgrave Macmillan.

Grillet-Aubert et al. Assessing shadow banking - non-bank financial intermediation in Europe No. 10, https://www.esrb.europa.eu/pub/pdf/occasional/20160727 occasional_paper_10.en.pdf.

Gorton, G., Metrick, A. (2012) “Securitized Banking and the Run on Repo," Journal of Financial Economics, Vol. 104, No. 3, pp. 425-51, http://www.sciencedirect. com/science/article/pii/S0304405X1100081X.

Hausman, J. A. (1978) "Specification Tests in Econometrics", Econometrica, Vol. 46, No. 6, pp. 1251-1271, http://links.jstor.org/sici?sici=0012-9682\%281978 $\mathrm{O} \% 3 \mathrm{~B} 2-\mathrm{X} \&$ origin $=$ repec.

Hodula, M., Machacek, M., Melecky, A. (2017) "Macroeconomic determinants of shadow banking: Evidence from Spain" In J. Proceedings of the 14th International Scientific Conference, Vol. 1, pp. 204-212, Brno: Masaryk University. https://obd.vsb.cz/fcgi/verso.fpl/fname/obd_public_det/id/286098669.

Hodula, M. (2018) "Off the Radar: Exploring the Rise of Shadow Banking in the EU", The Working Paper Series of the Czech National Bank (CNB) https:// www.cnb.cz/export/sites/cnb/en/economicresearch/.galleries/research_ publications/cnb_wp/cnbwp_2018_16.pdf.

Hodula, M. (2019) "Monetary Policy and Shadow Banking: Trapped between a Rock and a Hard Place”, Working Papers 2019/5, Czech National Bankhttps:// www.cnb.cz/export/sites/cnb/en/economiresearch/.galleries/research_ publications/cnb_wp/cnbwp_2019_05.pdf.

Hodula, M., Macháček, M., Meleck, A. (2020) "Placing the Czech Shadow Banking Sector under the Light", Prague Economic Papers Vol. 29 No. 1, pp. 3-28, doi: 10.18267/j.pep.710.

Hsiao, C. (1986) “Analysis of Panel Data. Econometric Society Monographs”, No. 11, New York: Cambridge University Press.

IMF. (2014) "Shadow Banking around the Globe: How Large, and How Risky? In Global financial stability report. Risk taking, liquidity, and shadow banking. Curbing excess while promoting growth", International Monetary Fund, Washington, DC, pp. 65-104, https://www.imf.org/en/Publications/GFSR/ Issues/2016/12/31/Risk-Taking-Liquidity-and-Shadow-Banking-CurbingExcess-While-Promoting-Growth.

Judson, R. A., Owen, L. A. (1999) "Estimating Dynamic Panel Data Models: A Guide for Macroeconomists", Economics Letters, Vol. 65, pp. 9-15, https:// faculty.smu.edu/millimet/classes/eco6375/papers/judson\%20owen\%201999. pdf. 
Jeffers, E., Plihon, D. (2016) "What is so special about European Shadow banking? FEPS Studies, Vol. 26.

Kim, S (2016) "What drives shadow banking? A dynamic panel evidence Eighth IFC Conference on Statistical implications of the new financial landscape" Basel, 8-9 September 2016.

Langfield, S., Pagano, M. (2016) "Bank bias in Europe: Effects on systemic risk and growth", Economic Policy, Vol. 31, No. 85, pp. 51-106, doi: 10.1093/ epolic/eiv019.

Lambin, J. (2014) "Rethinking the Market Economy: New Challenges, New Ideas, New Opportunities", Palgrave Macmillan.

Lysandrou, P., Nesvetailova, A. (2015) "The role of shadow banking entities in the financial crisis: A disaggregated view", Review of International Political Economy, Vol. 22, No. 2, pp. 257-279, doi:10.1080/09692290.2014.896269.

Loutskina, E. (2011) "The Role of Securitization in Bank Liquidity and Funding Management", Journal of Financial Economics, Vol. 100, No. 3, pp. 663-684. http://www.sciencedirect.com/science/article/pii/S0304-405X(11)00038-9.

Malatesta, F., Masciantonio, S., Zaghini, A. (2016) "The shadow banking system in the Euro area: Definitions, key features and the funding of firms", Italian Economic Journal, Vol. 2, No. 2, pp. 217-237, https://link.springer.com/ article/10.1007/s40797-016-0032-0.

Maddaloni, A. and Peydró, J.-L. (2011) "Bank risk-taking, securitization, supervision and low interest rates: evidence from the euro area and the US lending standards", Review of Financial Studies, Vol. 24, pp. 2121-2165.

Mehrling et al. (2013) "Bagehot was a Shadow Banker: Shadow Banking, Central Banking, and the Future of Global Finance", SSRN Electronic Journal, doi: 10.2139/ssrn.2232016.

Nelson, B., G. Pinter., Theodoridis, K. (2018) "Do Contractionary Monetary Policy Shocks Expand Shadow Banking?", Journal of Applied Econometrics, Vol. 33, pp. 198-211, https://doi.org/10.1002/jae.2594

Nesvetailova, A. (2018) Shadow Banking: Scope, Origins and Theories (Routledge Critical Studies in Finance and Stability) $1^{\text {st }}$ Edition.

Nickell, S. (1981) "Biases in Dynamic Models with Fixed Effects", Econometrica, Vol. 49, No. 6, pp. 1417-1426, https://doi.org/10.2307/1911408.

O'Sullivan, V., Kinsella, S. (2012) Chasing shadows: Europe prepares to regulate shadow banking Journal of Banking Regulation,Vol. 13, pp. 173-177, https:// link.springer.com/article/10.1057\%2Fjbr.2012.8.

Petkovski, M., Kjosevski, J., Jovanovski, K. (2018) "Empirical Panel Analysis of Non-Performing Loans in the Czech Republic. What are their Determinants and How Strong is Their Impact on the Real Economy?", Finance a úvěr-Czech Journal of Economics and Finance, Vol. 68, No. 5, http://journal.fsv.cuni.cz/ storage/1420_460_490_kjosevski_final_issue_05_2018.pdf. 
Portes, R. (2018) "Interconnectedness: Mapping the shadow banking system", Banque de France European Stability Review, pp. 2-10, https://repositori.upf.edu/ bitstream/handle/10230/35505/Ademu-WP-1172018\%20Interconnectedness. pdf? sequence $=1$ \&isAllowed $=\mathrm{y}$.

Pozsar, Z. (2008) "The rise and fall of the shadow banking system", Regional Financial Review, pp. 13-25, https://www.economy.com/sbs.

Pozsar, Z. et al. (2010) "Shadow banking", Federal Reserve Bank of New York Staff Report, No. 458, https://www.newyorkfed.org/medialibrary/media/ research/staff_reports/sr458.pdf.

Rinaldi L., Sanchis-Arellano, A. (2006) "Household Debt Sustainability, what Explains Household Non-Performing Loans?", An Empirical Analysis, Working Paper Series, No. 570, European Central Bank https://www.ecb.europa.eu/pub/ pdf/scpwps/ecbwp570.pdf.

Roodman, D. (2009) "How to do xtabond2: An introduction to difference and system GMM in Stata", The Stata Journal, Vol. 9, No. 1, pp. 86-136, https:// doi.org/10.1177/1536867X0900900106.

Svirydzenka, K. (2016) "Introducing a New Broad-Based Index of Financial Development", IMF Working Paper 16/5, https://www.imf.org/en/Publications/ WP/Issues/2016/12/31.

Wesley C.M. (2014) "Inside shadow banking: understanding the doomsday machine", European Journal of Economics and Economic Policies Intervention, Vol. 11, No. 3, pp. 315-332, doi: 10.4337/ejeep.2014.03.06. 


\title{
Utjecaj makroekonomskih i financijskih čimbenika na bankarstvo u sjeni u novim državama članicama EU-a
}

\author{
Kjosevski Jordan ${ }^{1}$, Mihail Petkovski ${ }^{2}$, Aleksandar Stojkov ${ }^{3}$
}

\begin{abstract}
Sažetak
Cilj ovog rada je ispitati kako različite varijable iz makroekonomskog $i$ financijskog okruženja utječu na dinamiku bankarskog sektora u sjeni u odabranih 11 novih država članica EU-a koristeći godišnje podatke za razdoblje 1999-2018. Primjenjuju se tri alternativne tehnike procjene: model s fiksnim efektima, metoda procjene GMM razlika i GMM sustava. Empirijski rezultati dokazuju da su najvažniji čimbenici razvoja u financijskom sektoru (sektoru osiguranja $i$ mirovinskom sektoru), bankarskom sektoru, te stopi na tržištu novca kao i opći ekonomski rast. Također je utvrđeno da globalna financijska kriza negativno utječe na rast bankarstva u sjeni. Dobiveni rezultati ukazuju na to da je bankarski sustav $u$ sjeni komplementaran, ne samo tradicionalnim bankama, već $i$ ostatku financijskog sustava, te otvara nova pitanja makrobonitetne politike imajući u vidu Basel III norme. Naime, jedan od glavnih ciljeva Basela III je smanjiti procikličnost bankarskog kreditiranja, a porast bankarstva u sjeni može utjecati kako na regulaciju koja se temelji na kapitalu tako i na ograničenja temeljena na dohotku.
\end{abstract}

Ključne riječi: bankarstvo u sjeni, nove države članice EU-a, panel analiza podataka

JEL klasifikacija: E44, E52, G21, G23

1 Doktor ekonomskih znanosti, neovisni istraživač Pitu Guli 5, Ohrid, Republika Makedonija. Znanstveni interes: makroekonomija, financijski menadžment. Tel.: +389 078 247 717. E-mail: jordan_kos@yahoo.com.

${ }^{2}$ Redoviti profesor, Ekonomski fakultet Sveučilišta Ss. Ćirila i Metoda u Skopskom bulevaru, Goce Delchev 9V, 1000 Skopje, Republika Makedonija. Znanstveni interes: financijska tržišta i institucije, međunarodne financije i makroekonomija.E-mail: mihail.petkovski@eccf.ukim. edu.mk.

${ }^{3}$ Redoviti profesor, Pravni fakultet Iustinianus Primus, Sveučilište Ss. Ćirila i Metoda u Skopju, Blvd. Goce Delchev 9b, 1000 Skopje, Republika Makedonija. Znanstveni interes: ekonomija, menadžment.E-mail: a.stojkov@pf.ukim.edu.mk. 